\title{
Genetic-morphometric variation in Culex quinquefasciatus from Brazil and La Plata, Argentina
}

\author{
Sirlei Antunes de Morais ${ }^{1}$, Camila Moratore ${ }^{2,3}$, Lincoln Suesdek ${ }^{2,3}$, Mauro Toledo Marrelli1/+ \\ ${ }^{1}$ Departamento de Epidemiologia, Faculdade de Saúde Pública ${ }^{3}$ Biologia da Relação Patógeno-Hospedeiro, Instituto de Ciências \\ Biomédicas, Universidade de São Paulo, São Paulo, SP, Brasil ²Seção de Parasitologia, Instituto Butantan, São Paulo, SP, Brasil
}

Variation among natural populations of Culex (Culex) quinquefasciatus Say is associated with different vectorial capacities. The species $\mathrm{Cx}$. quinquefasciatus is present in the equatorial, tropical and subtropical zones in the Brazilian territory, with intermediate forms between $\mathrm{Cx}$. quinquefasciatus and Culex pipiens occurring in regions of latitudes around $33^{\circ}-35^{\circ} \mathrm{S}$. Herein, we studied geographically distinct populations of $\mathrm{Cx}$. quinquefasciatus by genetic characterization and analysis of intra-specific wing morphometrics. After morphological analysis, molecular characterization of $\mathrm{Cx}$. quinquefasciatus and intermediate forms was performed by polymerase chain reaction of the polymorphic nuclear region of the second intron of the acetylcholinesterase locus. Additionally, the morphology of adult female wings collected from six locations was analyzed. Wing centroid sizes were significantly different between some geographical pairs. Mean values of $R_{2} / R_{2+3}$ differed significantly after pairwise comparisons. The overall wing shape represented by morphometric characters could be divided into two main groupings. Our data suggest that Brazilian samples are morphologically and genetically distinct from the Argentinean samples and also indicated a morphological distinction between northern and southern populations of Brazilian Cx. quinquefasciatus. We suggest that wing morphology may be used for preliminary assessment of population structure of Cx. quinquefasciatus in Brazil.

Key words: Culex pipiens complex - Culex quinquefasciatus - clines - molecular identification - wing morphology

The Culex (Culex) pipiens complex in the Americas is composed of two main species, Culex (Culex) quinquefasciatus Say, which is adapted to tropical zones and Cx. pipiens L., which is found in temperate zones. In intermediate areas, these two members can mate yielding hybrids and intermediate forms (Barr 1957), through the processes of gene flow and introgression (Humeres et al. 1998, McAbee et al. 2008, Kothera et al. 2009). Mosquitoes of the $C x$. pipiens complex are potential vectors of filarid worms in tropical and subtropical areas (Bockarie et al. 2009) and diverse arboviruses, including West Nile virus (Apperson et al. 2004, Cook et al. 2006).

Adult females and immature stages of the Cx. pipiens complex are morphologically similar. The differentiation of adult males can be made by analysis of genitalia, which includes measuring the DV/D ratio of the dorsal arms of the aedeagus in the phallosome, as reported by Sundararaman (1949). Because members of the $C x$. pipiens complex have a broad geographical distribution, other phenotypical differences beyond those of the male genitalia can be found. For example, some wing characters can also been used for morphologic identification of mosquito species.

Financial support: FAPESP (05/50225-2, 06/02622-5)

SAM and CM contributed equally to this work (FAPESP 06/57272-9 and $07 / 1665-5$, respectively).

+Corresponding author: mmarelli@usp.br

Received 24 November 2009

Accepted 29 April 2010
The taxonomic keys compiled by Forattini (2002) compared wing morphology of adult females. In that report, the subcosta vein $(\mathrm{Sc})$ was reported to bind with the costa vein $(C)$ before the bifurcation of the radial ${ }_{2+3}$ vein $\left(\mathrm{R}_{2+3}\right)$ in Cx. quinquefasciatus, whereas in Cx. pipiens, the $\mathrm{Sc}$ vein binds to vein $\mathrm{C}$ at the same point or beyond the $\mathrm{R}_{2+3}$ bifurcation. To our knowledge, these findings have not been investigated in other geographically distant populations.

Linam and Nielsen (1962) reported that Bekku (1956), in Northern Japan, also attempted to use wing characteristics [the length of radial cell $\mathrm{R}_{2}$ (second marginal cell) divided by the length of vein $\mathrm{R}_{3}$ ] to distinguish adults of the pipiens group. The results of Bekku (1956) were inconclusive, which was later explained when Kamura (1958) found that these particular wing measurements varied with the temperature of the environment. Nielsen and Rees (1961) and Linam and Nielsen (1962) reported that the most reliable method of separating females of $C x$. pipiens and $C x$. quinquefasciatus was by a wing measurement value obtained by dividing the length of the cell $R_{2}$ by the length of the vein $R_{2+3}\left(R_{2} / R_{2+3}\right.$ ratio). These authors reported the value of this ratio to be about 5.0 in Cx. pipiens and 3.0 or less in Cx. quinquefasciatus, with intermediate values present in the hybrids. However, these studies did not evaluate morphometric data among mosquito populations and climatic/geographic gradients.

In insects, the phenotypic variations among members of species complexes have been intensely investigated, especially those concerning the size and shape of adult wings (James \& Partridge 1998, Morin et al. 1999). In Drosophila, which has a worldwide distribution, significant morphometric wing variations were found in 
populations from different geographic regions, forming clusters or latitudinal clines (Van'T Land et al. 1999). Some studies report that variations in the wings may be related to intrapopulation genetic variations, life history [such as conditions during larval development (Swindell \& Bouzat 2006)], the direction of selection throughout the population sources (Hansen \& Houle 2008) and the fitness or possible targets of natural selection (Buggs 2007, Gay et al. 2008). Other studies have related morphological differences to species divergence or ecological adaptations (James et al. 1997).

The taxonomy of the Cx. pipiens complex is difficult to interpret, since members of the complex present several similarities in terms of both genetics and morphology. To correctly distinguish the taxa, morphological and molecular investigations are needed, as well as knowledge about the characteristics of populations throughout their biogeographical gradients. Likewise, the correct identification of females and hybrids is of epidemiological importance, mainly due to ecophysiological differences, which include autogeny, reproductive diapause, stenogamy, feeding behavior and vector potential (Humeres et al. 1998, Lenormand \& Raymond 2000, Fonseca et al. 2004, Savage et al. 2008).

Molecular markers have become an important tool to solve taxonomic problems and to identify sibling species. For example, Bourguet et al. (1998) reported variability at the nucleotide level of the acetylcholinesterase (ace-2) gene in several strains and natural populations of the Cx. pipiens complex. Few polymorphisms were found in coding regions within a subspecies, but many polymorphisms were observed between subspecies in noncoding regions. In their study, Bourguet et al. (1998) described a method based on a restriction enzyme polymorphism in polymerase chain reaction (PCR) amplified DNA, in which the presence or absence of a single restriction site discriminates between $C x$. pipiens, Cx. quinquefasciatus and their hybrids. This technique has since been used to reliably discriminate between mosquitoes from more than 30 worldwide strains or populations.

The present paper is a preliminary investigation of genetic-morphological variability of $C x$. quinquefasciatus in Brazil. In addition, the presence of a hybrid zone for Cx. quinquefasciatus and Cx. pipiens in Argentina is discussed. It also revises the morphological identification data of the females by morphometric characters of the wing.

\section{MATERIALS AND METHODS}

Mosquito samples - Immature stages of mosquitoes were collected in the field. Larvae were reared to adults in the laboratory and examined after emergence. The samples were collected in urban areas during the hot months of February and March of 2008, in the Brazilian municipalities of Teresina ( $\left.5^{\circ} 05^{\prime} \mathrm{S}\right)$, Rio Branco ( $\left.9^{\circ} 58^{\prime} \mathrm{S}\right)$,

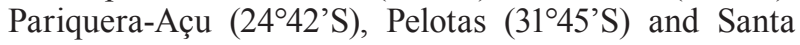
Vitória do Palmar ( $33^{\circ} 31^{\prime}$ S). Samples were also collected in the city of La Plata (345ㅗ' S), Argentina (Fig. 1). Sampling covered a latitudinal extension of $30^{\circ}$ throughout South America. Mosquitoes were identified as Cx. quinquefasciatus by analysis of morphologic characters, according to taxonomic keys in Forattini (2002). For wing

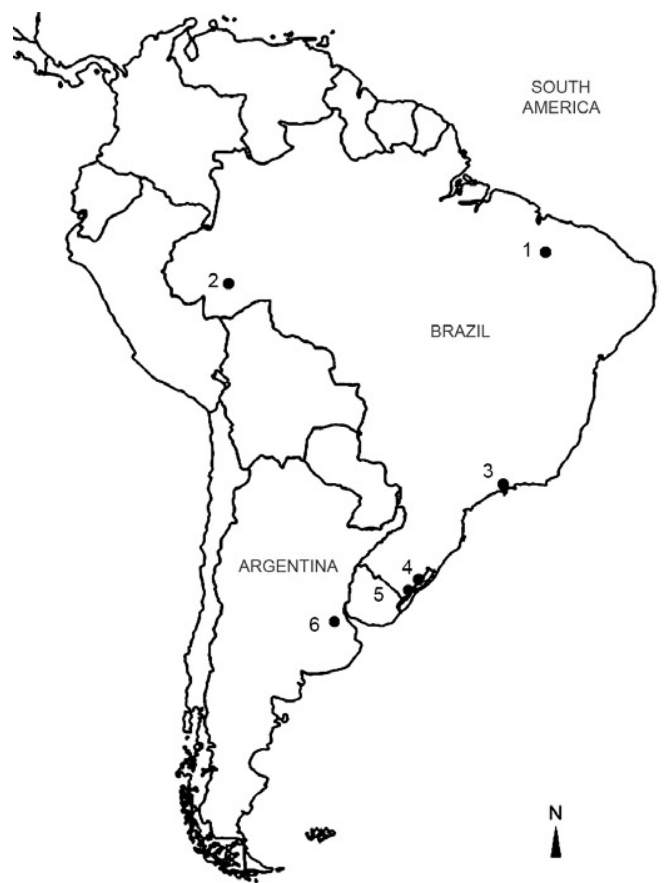

Fig. 1: Culex mosquito collection sites in South America. 1: Teresina; 2: Rio Branco; 3: Pariquera; 4: Pelotas; 5: Santa Vitória do Palmar (Brazilian municipalities); 6: La Plata (Argentina).

morphology and molecular analyses, only females were selected because species diagnosis is more difficult among female adults. Each individual was used for both analyses. DNA was extracted from whole bodies (without wings). Additionally, adult males were used for description of genitalia (phallosome) and calculation of DV/D ratio (Sundararaman 1949).

Nucleic acid isolation - After removing of the wings for morphometric analysis, genomic DNA was isolated from the remaining body parts using Qiagen DNeasy ${ }^{\circledR}$ Blood \& Tissue kits, following the manufacturer's recommendations with slight modification. DNA was eluted in a final volume of $100 \mu \mathrm{L}$ and stored at $-20^{\circ} \mathrm{C}$ until used for PCR.

PCR - Taxon-specific PCR primers based on polymorphisms in the second intron of the ace-2 locus were used to assist in distinguishing sibling species of $C x$. pipiens complex and to characterize populations and zones of hybridization (Bourguet et al. 1998, Aspen \& Savage 2003, Smith \& Fonseca 2004, Savage et al. 2007, Sanogo et al. 2008, Kothera et al. 2009). The fragment of the ace-2 locus was amplified from each DNA sample by PCR in a final reaction volume of $50 \mu \mathrm{L}$ with $2 \mathrm{mM} \mathrm{Mg}^{++}, 20 \mathrm{mM}$ Tris- $\mathrm{HCl}(\mathrm{pH} 8.4), 50 \mathrm{mM} \mathrm{KCl}, 0.5 \mathrm{mM}$ of each primer, $0.2 \mathrm{mM}$ dNTP mix, $2 \mathrm{U}$ of Taq DNA polymerase (Invitrogen) and approximately $6.0 \mathrm{ng}$ of genomic DNA.

We used multiplex forward and reverse primers for each species of interest: ACEquin 5'-CCTTCTTGAATGGCTGTGGCA-3', ACEpip 5'-GGAAACAACGACGTATGTACT-3', B1246s 5'-TGGAGCCTCCTCTTCACGG-3'. All primers were described by Smith 
and Fonseca (2004). The multiplex produces a 610-bp fragment in $C x$. pipiens, a 274-bp fragment in $C x$. quinquefasciatus and may produce one or both fragments in hybrids of the two species. The amplification program consisted of one cycle at $94^{\circ} \mathrm{C}$ for $5 \mathrm{~min}$, followed by 35 cycles at $94^{\circ} \mathrm{C}$ for $30 \mathrm{sec}, 55^{\circ} \mathrm{C}$ for 30 seconds, $72^{\circ} \mathrm{C}$ for $1 \mathrm{~min}$ and one cycle at $72^{\circ} \mathrm{C}$ for $5 \mathrm{~min}$.

Wing morphology - Wings of females from the following six locations were analyzed: Teresina $(\mathrm{n}=22)$, Rio Branco $(\mathrm{n}=27)$, Pariquera-Açu $(\mathrm{n}=28)$; Pelotas $(\mathrm{n}=22)$; Santa Vitória $(\mathrm{n}=22)$ and La Plata $(\mathrm{n}=31)$. Right wings were mounted on slides under a coverslip using Entellan. Photographs of wings were taken with a Leica DFC320 digital camera coupled to a stereomicroscope Leica S6 using 40X magnification.

In each wing image, coordinates of 18 landmarks (Fig. 2) were digitized using tpsDig software (v1.40 James Rohlf). Subsequent morphological analyses were performed according to Rohlf (1993). Computation of the $\mathrm{R}_{2} / \mathrm{R}_{2+3}$ ratio for each individual was performed using landmarks 4, 16 and 17, according to Nielsen and Rees (1961) and Linam and Nielsen (1962). Scores of this ratio were statistically compared within and among the six geographical samples.

Overall wing shape based on the 18 landmarks was compared among geographical samples through discriminant multivariate analysis. Following this analysis, we generated validated reclassification tests and a phenogram of Mahalanobis distances within each pair of samples. For overall wing size assessment, we used the centroid size as extracted from coordinates of the 18 landmarks. Morphometric analyses were performed using tpsRelw 1.44 (Rohlf 2006) and PAD softwares (Dujardin 2002) and graphical outputs were generated using Statistica 7.0 software (StatSoft).

\section{RESULTS}

Our results confirmed that $C x$. quinquefasciatus is distributed in the equatorial, tropical and subtropical zones in the Brazilian territory, with hybrids forms between $C x$. quinquefasciatus and $C x$. pipiens occurring in regions of latitudes around $34-35^{\circ} \mathrm{S}$, in La Plata. The multiplex PCR produced a 274-bp fragment in all specimens from Brazilian localities (Teresina, Rio Branco, Pariquera, Pelotas and Santa Vitória), identifying them as pure $C x$. quinquefasciatus populations. In the sample from La Plata (Argentina), three PCR band profile were found: (i) only the $274-\mathrm{bp}$ band (35\% of specimens), (ii) only the 610-bp band (23\%) and (iii) both bands (42\%).

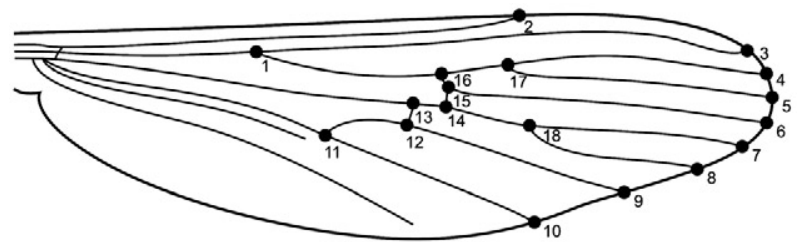

Fig. 2: wing of female of Culex mosquitoes with the 18 selected landmarks. Lines between 16-17 and between 17-4 define radial ${ }_{2+3}$ veins and $\mathrm{R}_{2}$, respectively.
These results suggest that La Plata is a hybrid region. Therefore, in this study, the samples collected in the Brazilian regions were labelled $C x$. quinquefasciatus (Q) and the samples from La Plata were labelled as a population of hybrid origin $(\mathrm{H})$. In another study (unpublished observations), $3 \%$ of the samples collected from Santa Vitória do Palmar in the winter showed fragments with both bands of ace-2. This suggested that the border of an area with high levels of hybridization area is approaching the latitude of $33^{\circ} \mathrm{S}$, in Brazil. Our findings are in accordance with the observations by Almirón et al. (1995) and Humeres et al. (1998), which indicated the presence of hybrids in the region of Argentina based on morphology of male genitalia, allele frequencies and experimental crosses. Those authors suggest latitudes between $33-35^{\circ} \mathrm{S}$ as a possible hybridization region.

Among Brazilian samples, populations from the tropical locations Teresina and Rio Branco had larger wings than subtropical areas (Pariquera, Pelotas and Santa Vitória do Palmar). Pairwise comparisons of samples from the six geographical regions using non-parametrical Kruskal-Wallis + Dunn's post-hoc test indicated significant differences in centroid size $(p<0.05)$ between Teresina and the others (except Rio Branco) and between Rio Branco and the others (except Teresina) (Fig. 3). No other pairs of samples differed significantly regarding the centroid size. These results suggest a temperaturedepended cline. Other studies have suggested that unlike wing shape, wing size may be a labile trait influenced by temperature (James et al. 1997, Gibert et al. 2004, Polak et al. 2004). However, it is currently difficult to perform a more profound interpretation of wing size data because wing size in culicids is reportedly also influenced by food availability (Jirakanjanakit et al. 2007).

The $\mathrm{R}_{2} / \mathrm{R}_{2+3}$ ratio scores of Brazilian samples were in accordance with the Cx. quinquefasciatus geographical zones, whereas the scores of Argentinean samples were similar to mosquitoes of hybrid origin, reported by Linam and Nielsen (1962) (Fig. 4). Comparisons using non-parametrical Kruskal-Wallis + Dunn's posthoc test indicated that samples from La Plata differed significantly $(p<0.001)$ from samples of the other five

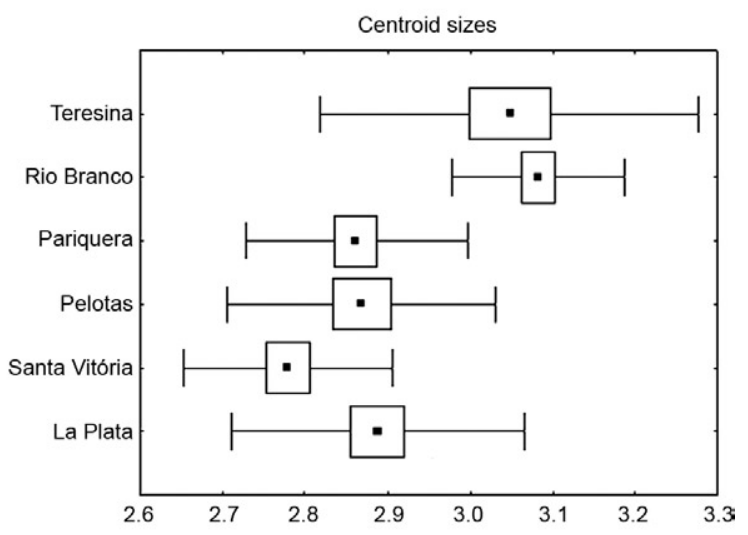

Fig. 3: centroid sizes, in millimeters. Black dot: mean; whiskers: standard deviation; boxes: standard error. 
geographical regions. No other pair of samples differed significantly regarding that ratio. These results may be indicative of low gene flow between $\mathrm{Q}$ and $\mathrm{H}$ populations because wing shape is genetically determined and has evolutionary significance (Dujardin 2008, Jirakanjanakit et al. 2008). A possible barrier to gene flow between $\mathrm{Q}$ and $\mathrm{H}$ would be the geographic distribution of Cx. pipiens, which appears to be climatically constrained to south of $33^{\circ} \mathrm{S}$, according to Almirón et al. (1995) and Humeres et al. (1998).

Discriminant analysis of wing shape data obtained from the 18 landmarks yielded a matrix of Mahalanobis distances, which is represented as a phenogram in Fig. 5. The overall wing shape showed a clear distinction among the Brazilian $(\mathrm{Q})$ and Argentinean $(\mathrm{H})$ samples, with two visible major clusters. Validated reclassification tests also showed that these two major clusters can be distinguished with $100 \%$ accuracy. Among Brazilian samples, there is an inner division separating northern (Teresina + Rio Branco) from southern (Pariquera + Pelotas + Santa Vitória) geographical samples.

Genetic data based on ace-2 amplification corroborated the morphological divergence between populations of Brazilian and Argentinean mosquitoes. Populations

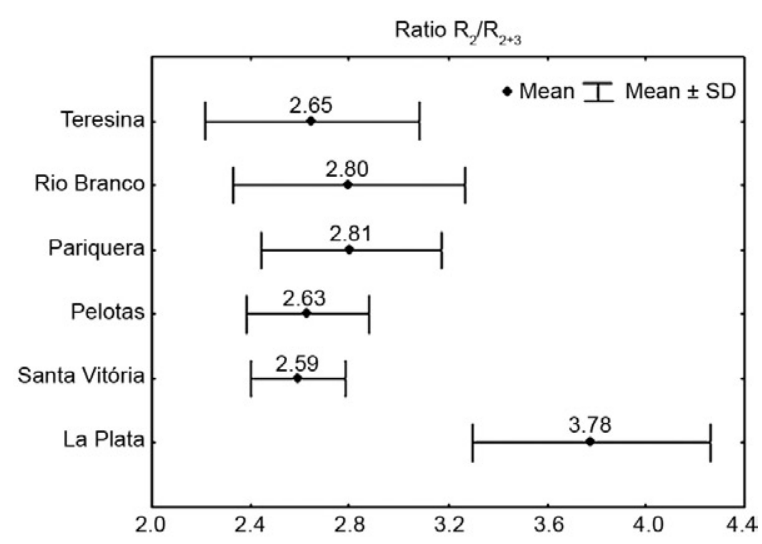

Fig. 4: descriptive whisker plot of radial cells $\mathrm{R}_{2} / \mathrm{R}_{2+3}$ ratio, means and standard deviation (SD).

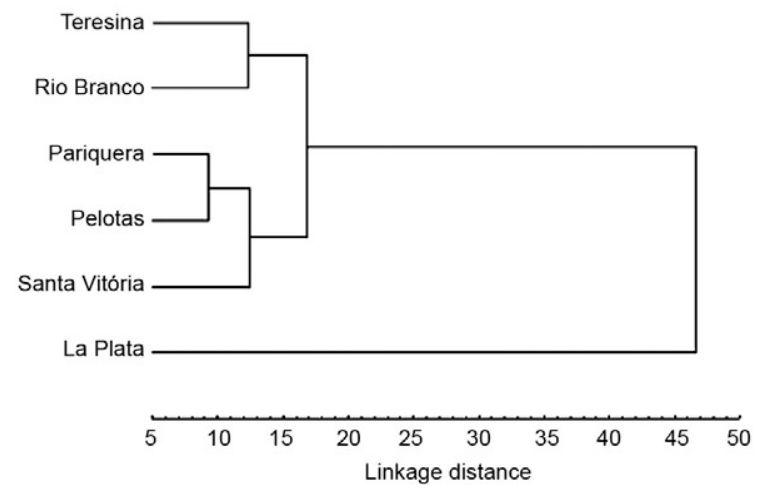

Fig. 5: phenogram with Mahalanobis distances among geographical samples (complete linkage amalgamation). from La Plata did not show a homogeneous banding pattern, indicating that this population may be composed of hybrids that originated from an introgression event between $C x$. quinquefasciatus and $C x$. pipiens species.

\section{DISCUSSION}

Our data suggest that the Brazilian populations of $C x$. quinquefasciatus sampled are morphologically and genetically distinct from the Argentinean population of La Plata. These results, which are similar to some observed in North America (Linam \& Nielsen 1962), indicate that wing characters may serve as diagnostic markers in future studies of the pipiens complex. However, more studies will certainly be needed to confirm such usefulness and to determine the geographical extension of the hybrid zone around La Plata.

Wing shape analysis also revealed a geographical population structure in the Brazilian samples. Northern samples, collected from a tropical zone, clustered separately from southern populations (collected from a subtropical zone), which leads us to believe that gene flow is lower between these two regions than within them. This conclusion is supported by the knowledge that wing shape can be indicative of population genetic structure since it is strongly determined by quantitative genetic heritage (Dujardin 2008). Morphological divergence between northern and southern samples might be enhanced by a geographical barrier, since the shortest linear distance between any pair of northern-southern locations (Teresina - Pariquera) is over $2100 \mathrm{~km}$. A morphoclimatic barrier consisting of the transition between tropical and subtropical zones is another hypothesis to be tested. Genetic data were homogeneous for the five Brazilian samples regarding this portion of ace-2, suggesting that $C x$. pipiens is not present in those Brazilian locations.

Male representatives of the three main wing morphological clusters exhibited the following DV/D mean ratios: Q-northern (Rio Branco) $=1.02 ;$ Q-southern $($ Pelotas $)=0.86$ and $\mathrm{H}($ La Plata $)=0.02$. Although these results are preliminary (sample sizes were 2, 4 and 2, respectively) and part of another survey in course, they are in accordance with the expected DV/D ratios: values near to zero are typical of Cx. pipiens (Sundararaman 1949). In addition, the overall shape of phallosomes of $\mathrm{H}$ samples and $\mathrm{H}$ samples were more similar to $C x$. quinquefasciatus and Cx. pipiens, respectively (data not shown). Thus, data from males reinforces the evidence that population $\mathrm{H}$ represents a hybrid zone. Differences between northern and southern Brazilian samples suggest that wing characters are also useful for a preliminary assessment of population structure of $C x$. quinquefasciatus in Brazil and should be helpful if utilized in population genetic surveys.

\section{ACKNOWLEDGEMENTS}

To Dr. Almério de Castro Gomes (School of Public Health, University of São Paulo), for providing mosquito samples from Teresina, to Gustavo Rossi (Centro de Estudios Parasitológi$\cos$ Y de Vectores, La Plata, Argentina), for providing specimens from La Plata, and to Ministry of Health (FUNASA) and Departments of Health of municipalities of Pelotas and Rio Branco, for helping us during the field works. 


\section{REFERENCES}

Almirón WR, Humeres SG, Gardenal CN 1995. Distribution and hybridization between Culex pipiens and Culex quinquefasciatus (Diptera: Culicidae) in Argentina. Mem Inst Oswaldo Cruz 90: 469-473.

Apperson CS, Hassan HK, Harrison BA, Savage HM, Aspen SE, Farajollahi A, Crans W, Daniels TJ, Falco RC, Benedict M, Anderson M, McMillen L, Unnasch TR 2004. Host feeding patterns of established and potential mosquito vectors of West Nile virus in the Eastern United States. Vector Borne Zoonotic Dis 4: 71-82.

Aspen S, Savage HM 2003. Polymerase chain reaction assay identifies North American members of the Culex pipiens complex based on nucleotide sequence differences in acetylcholinesterase gene ace-2. J Am Mosq Control Assoc 19: 323-328.

Barr AR 1957. The distribution of Culex p. pipiens and C. p. quinquefasciatus in North America. Am J Trop Med Hyg 6: 153-165.

Bekku H 1956. Studies on the Culex pipiens group of Japan. I. Comparative studies on the morphology of those obtained from various localities in the Far East. Nagasaki Igakkai Zasshi 31: 956-966.

Bockarie MJ, Pedersen EM, White GB, Michael E 2009. Role of vector control in the global program to eliminate lymphatic filariasis. Annu Rev Entomol 54: 469-487.

Bourguet D, Fonseca D, Vourch G, Dubois MP, Chandre F, Severini C, Raymond M 1998. The acetylcholinesterase gene ace: a diagnostic marker for the pipiens and quinquefasciatus forms of the Culex pipiens complex. J Am Mosq Control Assoc 14: 390-396.

Buggs RJ 2007. Empirical study of hybrid zone movement. Heredity 99: 301-312.

Cook S, Bennett SN, Holmes EC, De Chesse R, Moureau G, de Lamballerie X 2006. Isolation of a new strain of the flavivirus cell fusing agent virus in a natural mosquito population from Puerto Rico. J Gen Virol 87: 735-748.

Dujardin JP 2002. Permutations and discriminant analises (PAD). Available from: mpl.ird.fr/morphometrics.

Dujardin JP 2008. Morphometrics applied to medical entomology. Infect Genet Evol 8: 875-890.

Fonseca DM, Keyghobadi N, Malcolm CA, Mehmet C, Schaffner F, Mogi M, Fleischer RC, Wilkerson RC 2004. Emerging vectors in the Culex pipiens complex. Science 303: 1535-1538.

Forattini OP 2002. Culicidologia médica, Edusp, São Paulo, 860 pp.

Gay L, Crochet PA, Bell DA, Lenormand T 2008. Comparing clines on molecular and phenotypic traits in hybrid zones: a window on tension zone models. Evolution 62: 2789-2806.

Gibert P, Capy P, Imasheva A, Moreteau B, Morin JP, Pétavy G, David JR 2004. Comparative analysis of morphological traits among Drosophila melanogaster and D. simulans: genetic variability, clines and phenotypic plasticity. Genetica 120: 165-179.

Hansen TF, Houle D 2008. Measuring and comparing evolvability and constraint in multivariate characters. J Evol Bio 21: 1201-1219.

Humeres SG, Almirón WR, Sabattini MS, Gardenal CN 1998. Estimation of genetic divergence and gene flow between Culex pipiens and Culex quinquefasciatus (Diptera: Culicidae) in Argentina. Mem Inst Oswaldo Cruz 93: 57-62.

James AC, Azevedo RB, Partridge L 1997. Genetic and environmental responses to temperature of Drosophila melanogaster from a latitudinal cline. Genetics 146: 881-890.

James AC, Partridge L 1998. Geographic variation in competitive ability in Drosophila melanogaster. Am Nat 151: 530-537.

Jirakanjanakit N, Leemingsawat S, Dujardin JP 2008. The geometry of the wing of Aedes (Stegomyia) aegypti in isofemale lines through successive generations. Infect Genet Evol 8: 414-421.
Jirakanjanakit N, Leemingsawat S, Thongrungkiat S, Apiwathnasorn C, Singhaniyom S, Bellec C, Dujardin JP 2007. Influence of larval density or food variation on the geometry of the wing of Aedes (Stegomyia) aegypti. Trop Med Int Health 12: 1354-1360.

Kamura T 1958. Studies on the Culex pipiens group of Japan. 3. On the seasonal changes of morphological characters in Isahaya pallens. Nagasaki Igakkai Zasshi 33 (Suppl.): 78-85.

Kothera L, Zimmerman EM, Richards CM, Savage HM 2009. Microsatellite characterization of subspecies and their hybrids in Culex pipiens complex (Diptera: Culicidae) mosquitoes along a north-south transect in central United States. J Med Entomol 46: 236-248.

Lenormand T, Raymond M 2000. Analysis of clines with variable selection and variable migration. Am Nat 155: 70-82.

Linam JH, Nielsen LT 1962. Notes on the taxonomic separation of adult females of Culex pipiens L. and Culex quinquefasciatus Say. Mosq News 22: 290-293.

McAbee RD, Green EN, Holeman J, Christiansen J, Frye N, Dealey K, Mulligan FS 3rd, Brault AC, Cornel AJ 2008. Identification of Culex pipiens complex mosquitoes in a hybrid zone of West Nile virus transmission in Fresno County, California. Am J Trop Med Hyg 78: 303-310.

Morin JP, Moreteau B, Pétavy G, Parkash R, David JR 1999. Divergence of reaction norms of size characters between tropical and temperate populations of Drosophila melanogaster and D. simulans. J Evol Biol 12: 329-339.

Nielsen LT, Rees DM 1961. An identification guide to the mosquitoes of Utah. University of Utah Biological Series 12: 1-59.

Polak M, Kroeger DE, Cartwright IL, Ponce de Leon C 2004. Genotype-specific responses of fluctuating asymmetry and of preadult survival to the effects of lead and temperature stress in Drosophila melanogaster. Environ Pollut 127: 145-155.

Rohlf FJ 1993. Morphometric tools for landmark data. J Classification 10: 133-136.

Rohlf FJ 2006. tpsRelw, relative warps analysis, version 1.44. Department of Ecology and Evolution, State University of New York at Stony Brook.

Sanogo YO, Kim CH, Lampman R, Halvorsen JG, Gad AM, Novak RJ 2008. Identification of male specimens of the Culex pipiens complex (Diptera: Culicidae) in the hybrid zone using morphology and molecular techniques. J Med Entomol 45: 203-209

Savage HM, Aggarwal D, Apperson CS, Katholi CR, Gordon E, Hassan HK, Anderson M, Charnetzky D, McMillen L, Unnasch EA, Unnasch TR 2007. Host choice and West Nile virus infection rates in blood-fed mosquitoes, including members of the Culex pipiens complex, from Memphis and Shelby County, Tennessee, 2002-2003. Vector Borne Zoonotic Dis 7: 365-386.

Savage HM, Anderson M, Gordon E, McMillen L, Colton L, Delorey M, Sutherland G, Aspen S, Charnetzky D, Burkhalter K, Godsey M 2008. Host-seeking heights, host-seeking activity patterns and West Nile virus infection rates for members of the Culex pipiens complex at different habitat types within the hybrid zone, Shelby County, TN, 2002 (Diptera: Culicidae). J Med Entomol 45: 276-288.

Smith JL, Fonseca DM 2004. Rapid assays for identification of members of the Culex (Culex) pipiens complex, their hybrids and other sibling species (Diptera: Culicidae). Am J Trop Med Hyg 70: 339-345.

Sundararaman S 1949. Biometrical studies on intergradation in the genitalia of certain populations of Culex pipiens and Culex quinquefasciatus in the United States. Am J Hyg 50: 307-314.

Swindell WR, Bouzat JL 2006. Associations between environmental stress, selection history and quantitative genetic variation in Drosophila melanogaster. Genetica 127: 311-320.

Van'T Land J, Van Putten P, Zwaan B, Kamping A, Van Delden W 1999. Latitudinal variation in wild populations of Drosophila melanogaster: heritabilities and reaction norms. J Evol Bio 12: 222-223. 